\title{
Classical and Biblical Culture in Late Antique Egypt Some Notes
}

\author{
Lajos Berkes*
}

\begin{abstract}
This article discusses P.Gen. 4.159, a hexametric enkomion from the 6th c. AD, an allusion to Job in the petition, P.Cair. Masp. 1.67002 (567, Aphrodito) and the first attestation of the word prosynaxis in papyri (SB 18.13272).
\end{abstract}

Keywords: Hexametric enkomion, Job, petition, church, festive day

DOI 10.1515/apf-2015-0037

\section{P.Gen. 4.159: An enkomion on a deceased person?}

P.Gen. 4.159 (provenance unknown, 6th century) has been published as an 'éloge d'une personne décédée'. It consists of fragments containing the heading and several badly preserved lines of a hexametric poem. The text is of considerable interest, since there are only a few parallels for enkomia addressed to dead and not - as usually - to living persons. Two examples are by John Chrysostom (4- $5^{\text {th }}$ century), one elogium is from the $8-9^{\text {th }}$ century on John Chrysostom, and three others from the $14-15^{\text {th }}$ century. The addressees are in each case deceased church dignitaries. P.Gen. 4.159 would add another example to the scarcely known genre of enkomia on dead persons. ${ }^{1}$ It is, however, even more interesting that the deceased addressee of our text seems to have been a lay person, a vir magnificentissimus and not an ecclesiastical dignitary as in the other known examples. The interpretation of the text is based on the reading of the heading in the first two lines:

\footnotetext{
" Corresponding author: Lajos Berkes, Universität Heidelberg, Zentrum für Altertumswissenschaften, Institut für Papyrologie, Marstallstr. 6, 69117 Heidelberg, <lajos.berkes@ zaw.uni-heidelberg.de>

${ }^{1}$ For references see the introduction of P.Gen. 4.159.
} 


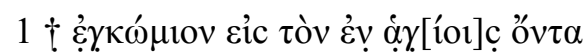

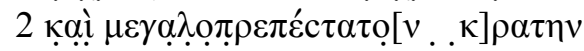

Consultation of the published photograph (Planche XXI) and the digital image available online $e^{2}$ raises, however, doubts about this reading. Paul Schubert kindly checked the original and I also benefited from discussion with Jean Gascou and Jean-Luc Fournet.

Paul Schubert reports that the papyrus is poorly preserved: it was glued on a sheet of paper. Also, the arrangement of the fragments is questionable. He has confirmed my suspicion that the left margin may well be incomplete. First of all, the second line refers to the supposedly deceased person as $\mu \varepsilon \gamma \alpha \lambda$ o $\pi \rho \varepsilon \pi \varepsilon$ c $\tau \alpha \tau o$ [ $[v$, but that adjective cannot apply to a dead person. One would rather expect a phrase like ó $\tau \hat{\eta} \varsigma \mu \varepsilon \gamma \alpha \lambda \mathrm{o} \pi \rho \varepsilon \pi \mathrm{o} \hat{\varsigma} \varsigma$

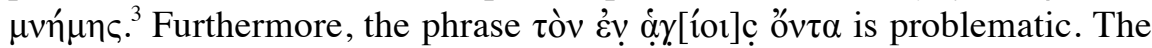
euphemism $\dot{\delta} \dot{\varepsilon} v \dot{\alpha} \gamma$ íors is fairly common in Byzantine papyri, ${ }^{4}$ but there are no examples for an added participle. In fact, the $\varepsilon$ of $\dot{\varepsilon} v$ resembles an alpha and the following letters are uncertain. Jean Gascou proposed to read $\dot{\varepsilon} v \delta o \xi o ́ \tau \alpha \tau o v$, but this would give an odd sequence, since this honorific is usually preceded by $\mu \varepsilon \gamma \alpha \lambda$ o $\pi \rho \varepsilon \pi \varepsilon ́ \sigma \tau \alpha \tau o \varsigma$. I have not been able to come up with a better solution for this line, but the reading $\dot{\varepsilon} v \dot{\alpha} \gamma[$ [ior]c

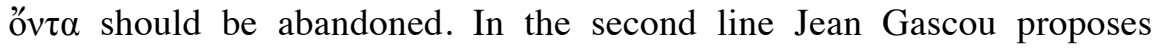

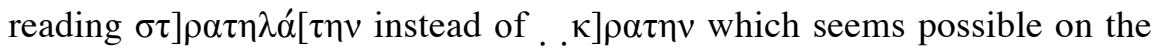
digital image.

Although the readings discussed are often dubious, it seems to be certain that the addressee of the enkomion was not a deceased person, but rather a living lay dignitary, a vir magnificentissimus. Accordingly, P.Gen. 4.159 may clearly be regarded to belong to the otherwise well known genre of hexametric enkomia on local magnates. Such poems are especially well known from the euvre of Dioscorus of Aphrodito, but there are also other examples. If Nereus is indeed mentioned in our text on fr. VIII, line 2, one might expect a mention of Thetis. This could suggest that the addressee is compared to Achilles, but this is mere speculation.

Finally, Jean Luc-Fournet reads in Fr. iv + v.3 ç̣̣ $\pi \lambda$ ọ́ov which is common at the beginning of hexameters in Nonnus, cf. e.g. Nonnus, Diony-

\footnotetext{
${ }^{2}$ See the relevant entry at $<$ http://www.ville-ge.ch/musinfo/bd/bge/papyrus/recherche. php $>$ (accessed on 30.07.2015).

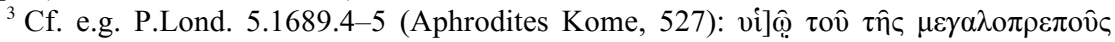

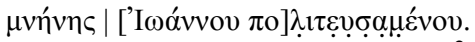

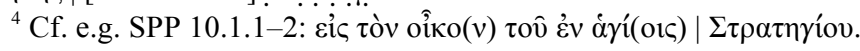


siaca $12.63 ; 23.158 ; 40.508$ etc. Thus the poem fits very well in the poetic landscape of Byzantine Egypt. ${ }^{5}$

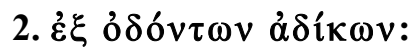 An allusion to Job in P.Cair. Masp 1.67002}

P.Cair. Masp 1.67002 (May 567) is among the most famous papyri from Byzantine Egypt. ${ }^{6}$ It contains the draft of a petition to Athanasios, the $d u x$ of the province Thebaid written by the famous poet and notary Dioscorus of Aphrodito. The inhabitants of the village Aphrodites Kome seek help against the pagarch Menas. They claim that Menas acted against their privilege of autopragia which guaranteed that they could deliver their taxes directly to the provincial capital. Menas is also accused of other violent deeds. Here I would like to focus on a passage of the beginning of the petition, lines 3-5:

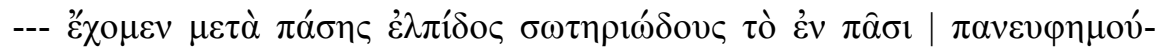

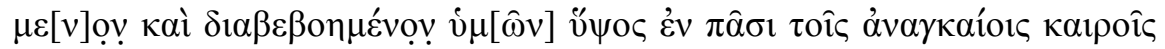

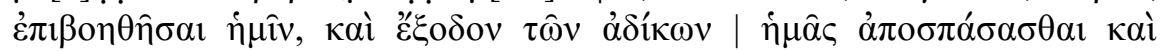

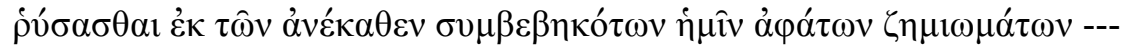

“... we set all our hopes of salvation upon your highness, who are among all men praised and bruited abroad, to help us in all our emergencies, to deliver us from the assault of unjust men, and to snatch us of the unspeakable sufferings..." (transl. by H.I. Bell) ${ }^{7}$

\footnotetext{
${ }^{5}$ Cf. L. Miguélez-Cavero, Poems in Context. Greek Poetry in the Egyptian Thebaid 200-600 AD (Sozomena Studies in the Recovery of Ancient Texts 2), Berlin/New York 2008.

${ }^{6}$ For bibliography see: J.-L. Fournet/J. Gascou, Liste des pétitions sur papyrus des VeVIIe siècles, in: D. Feissel/J. Gascou (ed.), La pétition à Byzance (Centre de Recherche d'Histoire et Civilisation de Byzance Monographies 14), Paris 2004, 141-196, 145-146. See also J.G. Keenan, "Tormented Voices": P.Cair. Masp. I 67002, J.-L. Fournet/ C. Magdelaine, Les archives d'Aphrodité cent ans après leur découverte. Histoire et culture dans l'Égypte byzantine. Actes du colloque de Strasbourg (8-10 décembre 2005) (Collection Études d'archéologie et d'histoire ancienne), Paris 2008, 171-180. An image can be consulted here: <http://www.misha.fr/papyrus_bipab/pages_html/P_Cair_Masp_I 67002.html> (accessed on 09. 07. 2015).

${ }^{7}$ H.I. Bell, An Egyptian Village in the Age of Justinian, JHS 64 (1944) 21-36, 33.
} 
I propose a different word division at the end of line 4, instead of

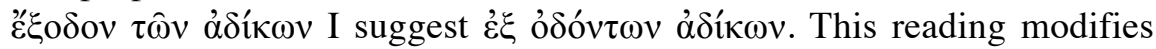
the meaning of the sentence: instead of "to deliver us from the assault of unjust men" the meaning is "to rescue ${ }^{8}$ us from the teeth of unjust men".

The proposed reading produces a grammatically smoother construction than the ed. pr. and results in a chiastic construction with the two verbs and the two $\grave{\varepsilon} \xi$ prepositions depending on them. One may still stumble over the phrase "teeth of unjust men". This alludes, however, to Job 29:17:

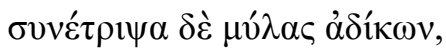

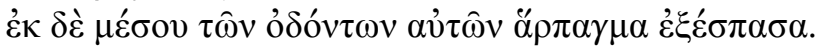

'I used to break the fangs of the wicked, And snatch their prey from their jaws."

This suggests that $\dot{\alpha} \delta$ ík $\omega v$ should not be understood as an adjective ('unjust teeth'), but a noun in our text. This verse was fairly popular in late antiquity. Beside commentaries on Job, it is cited several times by John Chrysostom. ${ }^{10}$ The $7^{\text {th }}$ century life of Theodor of Syceon ${ }^{11}(147.37-38)$

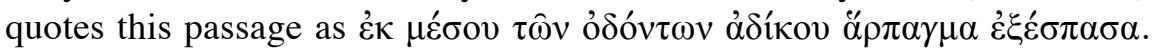
Dioscorus evokes a well-known Biblical passage and this allusion may be added to the intertextual network of this petition which contains other references to the Old Testament (Jonah, Judges, Genesis), but also to the Iliad. $^{12}$

\footnotetext{
${ }^{8}$ For the meaning of $\alpha \dot{\alpha} \sigma \sigma \pi \alpha \dot{\omega}$ (with examples for $\grave{c}_{\xi}$ ) cf. Lampe, Patristic Lexicon, s.v. 3.

${ }^{9}$ Translation from the The New Jerusalem Bible.

${ }^{10}$ E.g. Ad eos qui scand. 15; Adv. eos qui non adfuerant 482.46, 483.9. Other examples from John Chrysostom and later Byzantine authors can be easily found through the TLG.

${ }^{11}$ A.-J. Festugière (ed.), Vie de Théodore de Sykeon. I-II (Subsidia Hagiographica 48), Bruxelles 1970.

${ }^{12}$ J.-L. Fournet, Hellénisme dans l'Égypte du VIe siècle. La bibliothèque et l'œuvre de Dioscore d'Aphrodité II, (Institut Français d 'Archéologie Orientale du Caire Mémoires 115/2), Le Caire 1999, 674-677 and 680-682 and Fournet/Gascou (n. 6), 146.
} 


\section{The $\pi \rho \circ \sigma v v_{\alpha} \xi 1 \varsigma$ of the holy God-bearer: SB 18.13272}

SB 18.13272 is a receipt from the $8^{\text {th }}$ century Fayum. The text has been discussed on two occasions by Nikolaos Gonis, but some details are still obscure. ${ }^{13}$ The baker ( $\sigma i \lambda$ iyviópioc) Apollo made a payment of $1 / 3$ and $1 / 12$ artabe in wheat. He is associated to the church of holy Cosmas and Damianos and the payment is likely for a festive day. The first two lines were presented in the ed. $p r$. as follows:

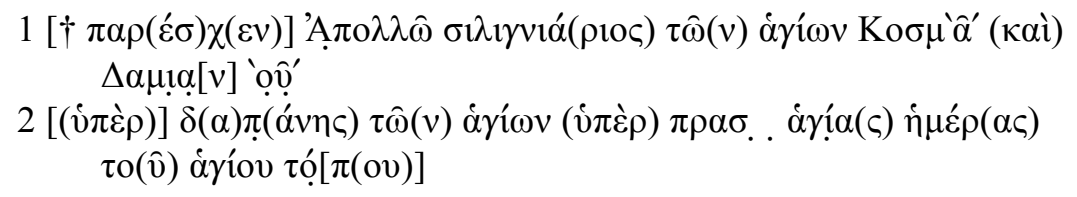

The editors commented on the second line: "( $(\dot{v} \pi \dot{\varepsilon} \rho)$ dürfte die Lücke am Anfang der Zeile, die etwa 2-3 Buchstaben fassen kann, ausgefüllt haben. - Das Schlüsselwort dieser Quittung bleibt uns unverständlich. Es ist vielleicht möglich, $\pi \rho \alpha ́ \sigma є \omega(\varsigma)$ zu lesen. Was ist aber mit „dem Kauf eines

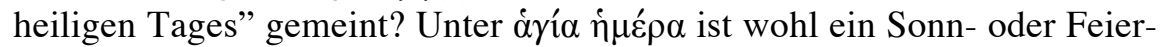
tag zu verstehen ... Handelt es sich um den Kauf eines Feiertages in einem von der Kirche abhängigen, geweihten Platz durch die Kirche von Kosmas und Damianos?" Gonis added: "Two successive constructions introduced

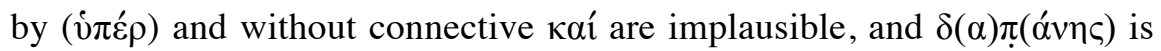
impossible ... The letter after the break is probably $\kappa$, and is followed by a suprascript letter, indicating an abbreviation. I am also baffled about what follows, but $\alpha \gamma i \underline{\alpha} \alpha(\varsigma)$ is certainly not there. I tentatively read $\pi \rho \omega \operatorname{cov} \xi()$, the abbreviation being that for $\varepsilon$ rather than $\alpha$. This ought to be a Greek word, but there is no obvious candidate (a form of $\pi \rho 0 \sigma \alpha v \xi \alpha$ $v \omega$ will not do). Whatever the case, this is not likely to have been a tax, but a payment made in connection with a festive day of the church of Kosmas and Damianos..."14

${ }^{13}$ Ed. pr.: G. Poethke/P.J. Sijpesteijn, Griechische Steuerquittungen früharabischer Zeit der Berliner Papyrus-Sammlung, APF 33 (1987) 73-77, 76-77. See the corrections by N. Gonis, Korr. Tyche 367, Tyche 15 (2000) 200, and Reconsidering Some Fiscal Documents from Early Islamic Egypt III, ZPE 169 (2009) 197-208, 204-205.

${ }^{14}$ Gonis, Reconsidering Some Fiscal Documents from Early Islamic Egypt III (n. 13), 205. 
Consultation of the digital image available online ${ }^{15}$ resulted in the following reading for the second half of line two: $\dot{v}(\pi \grave{\varepsilon} \rho) \pi \rho \omega \sigma v v \alpha \dot{\xi} \xi \varepsilon(\omega \varsigma)$

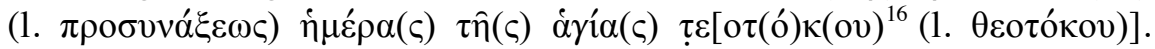
The shape of the $\omega$ in $\pi \rho \omega \sigma v v \alpha \xi_{\varepsilon} \varepsilon(\omega \varsigma)$ is the same as in 'A $\pi \mathrm{o} \lambda \lambda \hat{\omega}$ in the first line. For $\tau \varepsilon[o \tau(o ́) \kappa(o v)] \mathrm{cf}$. P.Rain. Unterricht 108v (Arsinoite, after 26. 7.

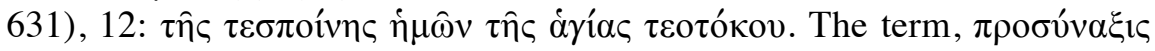
'Vorfest' has not yet been attested in papyri, but is known from 11th century Byzantium. ${ }^{17}$ The beginning of the line remains, however, unclear. After the $\kappa$ read by Gonis, I see a superscript $\lambda, \dot{\varepsilon} \kappa] \kappa \lambda(\eta \sigma i ́ \alpha \varsigma)$ is a

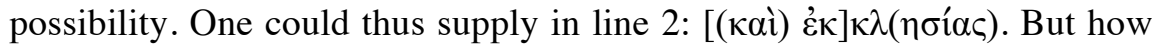

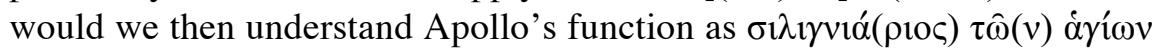

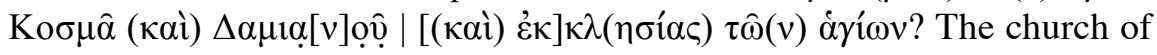
the two saints has already been attested (with the same abbreviation as is perhaps preserved in our papyrus) in SPP 3.269.3 (Arsinoite [?], 7-8 ${ }^{\text {th }}$

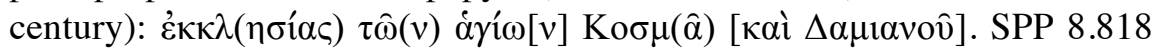
(Arsinoite, $8^{\text {th }}$ century) is a tax receipt issued for another $\sigma i \lambda \imath \gamma v$ ióploc called Apollos, but there is no apparent connection between the two texts. SB 16.13016.14-15 (Arsinoiton Polis, 638) is also comparable, where the

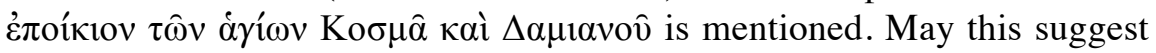
that our Apollo was the baker of the ह̇лoíkıv and the church? Was the $\dot{\varepsilon} \pi$ oíkiov connected to the church of Kosmas and Damianos in Arsinoiton Polis? The hamlet was perhaps managed by the church. Alternatively, the second line might have begun with кaí and another function of Apollo. The superscript letter may be an ugly minuscule delta as well. This may point to $[(\kappa \alpha i)$ oi $] \kappa(o) \delta(o ́ \mu o \varsigma)$, but this supplement seems to be too short

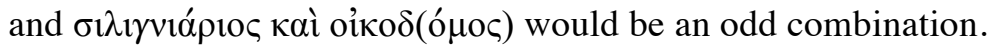

Finally, it seems to be worthwhile to provide a new text of the receipt including all the corrections which have been suggested so far. The text includes some tacit changes in dotting, brackets and the indication of superscript letters:

\footnotetext{
${ }^{15}$ A link to the image can be foud in the HGV-record of the text.

${ }^{16}$ The abbreviation is given only e.g. The word must have been abbreviated, since there is not enough space in the lacuna for the word written out in full.

${ }^{17}$ E. Trapp (ed.), Lexikon zur byzantinischen Gräzität, besonders des 9-12. Jahrhunderts, VII (Österreichische Akademie der Wissenschaften, Philosophisch-Historische Klasse Denkschriften; Veröffentlichungen der Kommission für Byzantinistik), Wien 2011, s.v.
} 


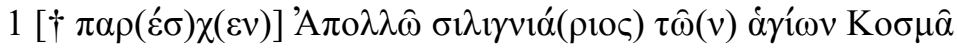

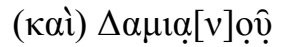

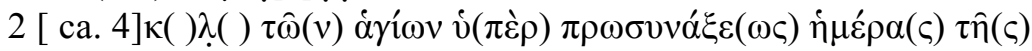
$\dot{\alpha} \gamma \mathbf{i}^{\prime} \alpha(\varsigma) \tau \varepsilon[\mathrm{o} \tau(\mathrm{o}) \kappa(\mathrm{ov})]$

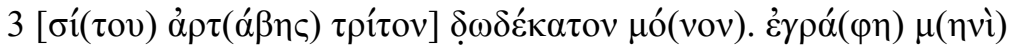
$\Pi(\alpha) \chi(\omega v)$. iv $\delta(1 \kappa \tau i ́ \omega v o \varsigma)$. [

vac.

$4 \quad$ vac. $\left.\quad \gamma^{\prime}(v \varepsilon \tau \alpha \imath) \sigma i ́(\tau o v) \dot{\alpha} \rho \tau(\alpha \dot{\beta} \beta\rceil\right) \gamma^{\prime}{ }^{\prime} \beta^{\prime}$.

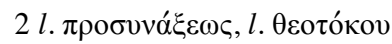

' Apollo, the baker of saint Cosmas and Damianos ... the saints, has paid for the prosynaxis of the day of the holy God-bearer of an artabe of wheat one third and one twelfth only. It was written in the month Pachon, on the ... of the ... indiction.

In total of an artabe of wheat $1 / 31 / 12$.' 